\title{
Validated Stability -Indicating UPLC Method for Determination of Dapoxetine and Fluoxetine: Characterization of Their Hydrolytic Degradation Products, Kinetic Study and Application in Pharmaceutical Dosage Forms
}

Suzan Mahmoud Soliman ${ }^{1 *}$, Heba MY El-Agizy' and Abd El Aziz El Bayoumi ${ }^{2}$

${ }^{1}$ National Organization for Drug Control and Research (NODCAR), Giza, Egypt

${ }^{2}$ Analytical Chemistry Departments, Faculty of Pharmacy, Cairo University, Cairo, Egypt

\begin{abstract}
New isocratic stability-indicating reversed phase UPLC method was developed for determination of two antidepressant drugs dapoxetine hydrochloride (DAP) and fluoxetine hydrochloride (FLX) in the presence of their hydrolytic degradation products namely; (+)-N, N-dimethyl-1-phenyl-3-propanolamine (DAP Deg I), N-methyl3-hydroxy-3-phenyl propyl amine (FLX Degl), a, a, a-Trifluorotoluene (FLX Deg II) and application in their pharmaceutical dosage forms.

UPLC method using small sub-1.8 $\mu \mathrm{m}$ particle was developed for separation and determination of the selected drugs using Agilent Eclipse XDB C18 $(50 \mathrm{~mm} \times 2.1 \mathrm{~mm}$ i.d., $1.8 \mu \mathrm{m})$ column. Upon using UPLC, the run time could be reduced 5 -fold and the solvents consumption decreased 10 tims. Quantification is achieved by detection wavelength at $210 \mathrm{~nm}$, based on peak area. The linear ranges were $0.05-100 \mu \mathrm{g} / \mathrm{mL}$ and $0.30-100 \mu \mathrm{g} / \mathrm{mL}$ with LOD of 0.01 and $0.09 \mathrm{mg} \mathrm{mL}^{-1}$ and mean recoveries of $99.41 \pm 1.02$ and $100.05 \pm 0.89$ for DAPand FLX, respectively, the developed method was successfully applied to analysis of DAP and FLX in bulk powder, laboratory-prepared mixtures containing different percentages of degradation products and pharmaceutical dosage forms.

UPLC method was also directed to investigate the degradation kinetic processes of both drugs. It was followed pseudo-first order reactions with a degradation reaction rate constant $(\mathrm{k})$ of $0.0575\left(\mathrm{~h}^{-1}\right)$ and $0.965\left(\mathrm{~h}^{-1}\right)$ and half-life $\left(\mathrm{t}_{1 / 2}\right)$ of 12.04 and $0.75(\mathrm{~h})$ for DAP and FLX, respectively. The degradation rate $(\mathrm{k})$ obeyed Arrhenius equation and the activation energies were calculated. The degradation products (I-III) were separated by UPLC and subjected to MS spectrometry to confirm their structures and elucidate degradation pathway. The developed methods were validated as per $\mathrm{ICH}$ guidelines.
\end{abstract}

Keywords: Dapoxetine; Fluoxetine; Stability-indicating UPLC-MS; Kinetic investigation; Structural elucidation

\section{Introduction}

Major depressive disorder (MDD), depression, is one of the most common and widespread mental disorders in our society. It affects approximately 216 million people (3\% of the world's population) [1,2].

Dapoxetine $\mathrm{HCl}(\mathrm{DAP})$ and fluoxetine $\mathrm{HCl}$ (FLX) are antidepressant drugs of the selective serotonin reuptake inhibitors (SSRIs) class. They are used for the treatment of major depressive and obsessivecompulsive disorders. Clinical studies have shown that after treatment with SSRI drugs, intravaginal ejaculation latency time gradually increased as a side effect in men [3]. Dapoxetine is a short acting oral SSRI, it cannot permanently cure premature ejaculation PE but has increased in importance due to fewer side effects. It has a much lower ejaculation-delaying effect compared with FLX. SSRIs appear to be the most important therapeutic drugs for PE with regard to their multiple sites of action in the regulation of the complex mechanisms involved in ejaculation. Therefore, SSRIs have opened a new potential avenue for PE treatment. According to the European Association of Urology (EAU) guidelines, daily treatment with SSRI has become the first-choice treatment in PE. It is postulated that on-demand (acute) treatment with SSRI, such as dapoxetine, will not produce an ejaculation delay equivalent to daily long-term (chronic) treatment of SSRI, such as fluoxetine $[3,4]$.

Chemically DAP is recognized as (S)-N, N-dimethyl-3-(naphthalen1-yloxy)-1-phenyl propan-1- amine hydrochloride [5]. Whereas FLX is ( \pm ) - [N-methyl-3-phenyl-3-[4-(trifluoromethyl)-phenoxy] propan-1amine] hydrochloride [5].
Dapoxetine is not official in any Pharmacopeia. In the literature survey, several reports have been established for analysis of DAP either alone or in combined pharmaceutical dosage forms such as synchronous fluorescence spectroscopy [6] TLC densitometry [7], CZE [8], and liquid chromatography $[9,10]$ using different columns and various mobile phases.

Few methods have been published for the stability indicating determination of DAP in the presence of unknown degradation products formed through forced degradation studies. Most of the methods were related with chromatographic techniques such as HPLC [11-15] using different mobile phases and various detection modes, but no attempt has been carried out for characterization of degradation products. To best of our knowledge, there is only one stability-indicating UPLC with diode array detection was carried out for quantification of DAP along with sildenafil [16]. However, these

*Corresponding author: Suzan Mahmoud Soliman, National Organization for Drug Control and Research (NODCAR) El Agoza, Giza, 12311, Egypt, Tel: +20226496077; Fax: +20223379445; E-mail: suzansoliman1961@hotmail.com

Received November 20, 2017; Accepted December 22, 2017; Published December 30,2017

Citation: Soliman SM, El-Agizy HMY, El Bayoumi AEA (2017) Validated Stability -Indicating UPLC Method for Determination of Dapoxetine and Fluoxetine: Characterization of Their Hydrolytic Degradation Products, Kinetic Study and Application in Pharmaceutical Dosage Forms. Pharm Anal Acta 8: 571. doi: 10.4172/21532435.1000571

Copyright: @ 2017 Soliman SM, et al. This is an open-access article distributed under the terms of the Creative Commons Attribution License, which permits unrestricted use, distribution, and reproduction in any medium, provided the original author and source are credited. 
Citation: Soliman SM, El-Agizy HMY, El Bayoumi AEA (2017) Validated Stability -Indicating UPLC Method for Determination of Dapoxetine and Fluoxetine: Characterization of Their Hydrolytic Degradation Products, Kinetic Study and Application in Pharmaceutical Dosage Forms. Pharm Anal Acta 8: 571. doi: 10.4172/2153-2435.1000571

Page 2 of 10

methods were associated with some major drawbacks such as the use of gradient-system program that had increased solvents consumption and quantified the drug in high cost of analysis [13,15,16], also there was a lack of selectivity and relatively high retention time [15].

On the other hand, the quantification of FLX in pharmaceutical formulations were addressed in several reports including; Spectrophotometry [17], Spectro fluorimetry [17], GC [18], CE [19], HPTLC $[20,21]$ and, liquid chromatography methods [20-23] using various detection modes.

In the literature survey, few methods have been developed for the stability indicating assay of FLX in combination with other drugs including; HPTLC densitometry [24] and HPLC via diode array detection [25] and UV detection [26].

Unfortunately, these methods were associated some limitations such as increasing the cost of analysis, solvent consumption and analysis time, particularly due to the use of gradient elution mode [25] and the relatively high retention time $(20 \mathrm{~min})$ [26]. In addition, no data published for identification and characterization of FLX degradation products [24-26].

Recently UPLC methods for the simultaneous determination of FLX and its active metabolite in biological samples have been reported with Risperidone [27] or Clomipramine [28]. To best of our knowledge, there is no stability-indicating UPLC for the determination of FLX in presence of its degradarion products (I, II) with its application in pharmaceutical formulation.

UPLC is a recent technique giving new possibilities in liquid chromatographic separation, which enables significant decrease of time of analysis and solvent consumption. UPLC system is designed in a special way to withstand high system back-pressures. Special columns packed with $1.7 \mu \mathrm{m}$ particles size are used about this UPLC system. It allows reduction in time of analysis up to 9 folds comparing to the conventional HPLC using $5 \mu \mathrm{m}$ particle packed columns [29].

The proposed UPLC method for analysis of DAP and FLX in their pharmaceutical preparations has been developed (for the first time) in presence of their major degradation products confirmed as $(+)-\mathrm{N}$, $\mathrm{N}$-dimethyl-1-phenyl-3-propanolamine, N-methyl-3-hydroxy-3phenyl propyl amine and, $\alpha, \alpha, \alpha$-Trifluorotoluene. Up till now neither isocratic stability-indicating UPLC nor degradation kinetic study of DAP and FLX has been reported, therefore our target is to develop a simple, rapid, economical, reproducible, fully validated and alternative isocratic stability-indicating UPLC method for quantifying DAP and FLX in presence of their degradates (I-III) with good detection limits in drug substances and products that will overcome the above-mentioned drawbacks (Figure 1).

\section{Experimental Instruments}

UPLC system Agilent, USA, 1200 series, consisted of a binary pump SL(G131213) equipped with an autosampler injector ALS SL(G132913) and a photo diode array detector (PDAD) (G1315C). The chromatographic separations were performed at $25^{\circ} \mathrm{C}$ using Agilent Eclipse XDB C18 (50 mm x $2.1 \mathrm{~mm}$ i.d., $1.8 \mu \mathrm{m}$ particle size). $\mathrm{pH}$ measurements were carried out using a digital $\mathrm{pH}$ meter (Hanna pH211, Romania). TLC aluminum sheets $(20 \times 20 \mathrm{~cm}, 0.2 \mathrm{~mm})$ Silica gel F254 (Merck KGaA Darmstadt, Germany) and a UV lamp with a short wavelength of $254 \mathrm{~nm}$ (Desaga Germany) were used for identification by TLC. The mobile phases were filtered through 0.45 $\mu \mathrm{m}$ Millipore membrane filters (Sartorius, Germany). A thermostatic water bath (Memmert, Germany), a Rotavapor (Buchi, Switzerland), a sonicator (crest, New York) were used. Hamilton syring with a $10 \mu \mathrm{l}$ capacity was used.

\section{LC/MS}

The HPLC apparatus consisted of Accela 1200 LC-10AD pump, auto sampler Accela and a Hypersill gold Phenomenex $(50 \mathrm{~mm} \times 2.0$ $\mathrm{mm}$ i.d., $2.1 \mu \mathrm{m}$ particle size) column preceded by a C18 security guard cartridge Gemini C18 Phenomenex (4 mm x $3 \mathrm{~mm}$ i.d., $5 \mu \mathrm{m}$ particle size).

Mass spectrometric analysis was carried out using a TSQ Quantum Access MAX triple quadrupole detection system. Data acquisition was performed in Full scan mode. Processing of data is performed using Thermo Scientific Xcalibur 2.1 software.

\section{Materials}

\section{Authentic samples}

Dapoxetine $\mathrm{HCl}$ standard material $(99.22 \pm 1.35 \%)$ was kindly supplied by Inspire Pharma. Its purity was assessed using the reported HPLC method. The determination of the drug was done using a mobile phase consisting of Methanol- $\mathrm{H}_{2} \mathrm{O}(80: 20 \mathrm{v} / \mathrm{v})$ with quantification at a wavelength at $239 \mathrm{~nm} \mathrm{[12].}$

Fluoxetine $\mathrm{HCl}$ standard material was kindly supplied by Eli Lilly Company. Its purity was certified to be $(99.29 \pm 1.54 \%)$ using cetonitrile-methanol-0.032 $\mathrm{M}$ ammonium acetate buffer (45:05:50, $\mathrm{v} / \mathrm{v} / \mathrm{v})$ as the mobile phase as the mobile phase with quantitation at 235 $\mathrm{nm}[21]$.

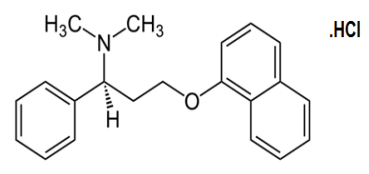

(a)

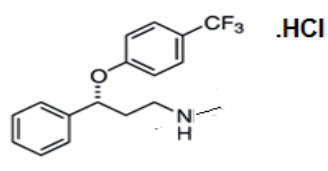

(b)<smiles>CN(C)[C](CCO)c1ccccc1</smiles>

(c)<smiles>CNCCC(O)c1ccccc1</smiles>

(e)

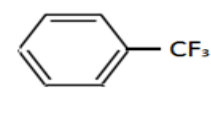

d)

Figure 1: Chemical structures of the studied drugs and their degradation products: (a) Dapoxetine HCI DAP, (b) Fluoxetine HCI FLX, (c) (+)-N,N-dimethyl-1-phenyl3-propanolamine (DAP Deg I), (d) N-methyl-3-hydroxy-3-phenylpropylamine (FLX Deg I) and (e) a, a, $\alpha$-Trifluorotoluene (FLX Deg II). 
Citation: Soliman SM, El-Agizy HMY, El Bayoumi AEA (2017) Validated Stability -Indicating UPLC Method for Determination of Dapoxetine and Fluoxetine: Characterization of Their Hydrolytic Degradation Products, Kinetic Study and Application in Pharmaceutical Dosage Forms. Pharm Anal Acta 8: 571. doi: 10.4172/2153-2435.1000571

\section{Market samples}

Joypox tablets (batch No \# 0912109) were kindly supplied by Inspire Pharma (Cairo,Egypt). Each tablet was labeled to contain 60 mg dapoxetine base.

Prozac capsules (batch No \# 1014B) were kindly supplied by Lilly S.A (Spain) (Cairo, Egypt), Each capsule was labeled to contain $20 \mathrm{mg}$ fluoxetine base.

\section{Chemicals and solvents}

Chromatographic grade, scetonitrile and methanol were obtained from (Lab-Scan, Poland). Ammonium acetate (Fischer Chemical, UK), triethylamine (LOBA Chemie, India) and acetic acid glacial (Biosolve Chimie SARL, France) were of analytical grade. Double distilled water was used to prepare all necessary solutions.

\section{Standard solutions}

Stock standard solutions of $1 \mathrm{mg} \mathrm{mL}^{-1}$ of each of DAP and FLX were prepared in the mobile phase, the working standard solutions were separately prepared by convenient dilution of their stock standard solutions with the corresponding mobile phase to obtain standard solutions of $0.1 \mathrm{mg} / \mathrm{ml}$ and $0.2 \mathrm{mg} \mathrm{mL}^{-1}$ of DAP and FLX, respectively.

\section{Chromatographic conditions}

The chromatographic separation was achieved on a reversed phase Agilent Eclipse XDB C18 (50 mm x $2.1 \mathrm{~mm}$ i.d., $1.8 \mu \mathrm{m}$ particle size) column. An isocratic mobile phase consisting of a mixture of aqueous $0.03 \mathrm{M}$ ammonium acetate, $\mathrm{pH}$ 4.2-acetonitrile (35: 65, v/v) was used for separation and quantification of DAP. A mixture of aqueous 0.03 $\mathrm{M}$ triethylamine, $\mathrm{pH} 4.3$ (adjusted with glacial acetic acid) -acetonitrile $(40: 60, v / v)$ was used for the chromatographic analysis of FLX. The prepared mobile phase was degassed in an ultrasonic bath for $10 \mathrm{~min}$ and then filtered using a vacuum pump. Determination was performed at $0.2 \mathrm{~mL} \mathrm{~min}^{-1}$ flow rate with injection volumes $0.8 \mu \mathrm{L}$ and detection wavelength $210 \mathrm{~nm}$. All measurements were carried out at ambient temperature $\left(25^{\circ} \mathrm{C} \pm 2\right)$ for both drugs. To achieve good equilibrium, the column was pre-conditioned with the mobile phase before analysis at ambient temperature about $20 \mathrm{~min}$.

\section{Procedures}

\section{Linearity and construction of the calibration curves}

Aliquots of DAP $\left(0.1 \mathrm{mg} \mathrm{mL}^{-1}\right)$ and FLX $\left(0.2 \mathrm{mg} \mathrm{mL}^{-1}\right)$ working standard solutions were separately transferred into series of 10 $\mathrm{ml}$ volumetric flasks to get final concentration range of (0.05-100 $\mu \mathrm{g} \mathrm{mL}^{-1}$ ) and (3-100 $\left.\mu \mathrm{gmL}^{-1}\right)$ for DAP and FLX, respectively, in the corresponding mobile phase. Triplicate $0.8 \mu \mathrm{L}$ injections were performed for each concentration and chromatographed under the specified chromatographic conditions described previously. The peak area values were plotted against corresponding concentrations, and the regression equations were computed.

\section{Stability study of DAP and FLX}

$100 \mathrm{mg}$ of each of DP and FLX powder was transferred into 250 $\mathrm{ml}$ round bottom flask, dissolved in $100 \mathrm{ml}$ of $5 \mathrm{M} \mathrm{HCl}$ solution. The two flasks were tightly closed away from light and left for 30 and $2 \mathrm{~h}$ at thermostatically controlled water bath set at $90^{\circ} \mathrm{C}$ and $80^{\circ} \mathrm{C}$ for DAP and FLX, respectively. The complete degradation processes of the two drugs were followed by TLC using toluene-methanol $(8.5: 1.5 \mathrm{v} / \mathrm{v})$ and toluene -glacial acetic acid $(5: 5 \mathrm{v} / \mathrm{v})$ as developing systems to achieve complete degradation of DAP and FLX, respectively. The developed plates were visualized at $254 \mathrm{~nm}$ under a UV lamp.

The acidic degradation products solutions were neutralized with $5 \mathrm{M}$ $\mathrm{NaOH}$ to $\mathrm{pH} 7$ and then evaporated until dryness in Rotavapor water bath at $70^{\circ} \mathrm{C}$ and cooled. The residues of the hydrolytic degradation products were separately dissolved in $50 \mathrm{ml}$ methanol and filtered to exclude sodium chloride formed during the neutralization process. The solutions were further re-evaporated until dryness. The residues of degradation products were separately dissolved in $100 \mathrm{~mL}$ methanol to get stock solutions of $\left(1 \mathrm{mg} \mathrm{mL}^{-1}\right)$ for each degradate. Further dilution was prepared in mobile phase to obtain working standard solutions of $\left(0.1 \mathrm{mg} / \mathrm{ml}\right.$ of DAP degradate) and $\left(0.2 \mathrm{mg} \mathrm{mL}^{-1}\right.$ of FLX degradate).

The obtained degradation products were identified by mass spectrometry.

a) Laboratory prepared mixtures containing different ratios of DP and its hydrolytic degradation product (DegI)

Several laboratory prepared mixtures of DAP and its degradation product (I) were prepared in the range of $(10-90 \% \mathrm{w} / \mathrm{w})$.

b) Laboratory prepared mixtures containing different ratios of FLX and its hydrolytic degradation products (DegI\&II)

Several laboratory prepared mixtures of FLX and its degradation products (I\&II) were prepared in the same range.

The prepared mixtures were analyzed by the proposed method as described under chromatographic conditions where the concentrations of the intact drug in each mixture was calculated from the corresponding regression equation.

\section{Application to pharmaceutical formulation}

The content of ten Joypox ${ }^{\oplus}$ tablets and content of ten Prozac ${ }^{\circledR}$ capsules was separately weighed and ground. A portion of the ground powder equivalent to $100 \mathrm{mg}$ of each drug was accurately weighed, transferred separately to $100 \mathrm{ml}$ volumetric flask, dissolved in $80 \mathrm{~mL}$ of the mobile phase using ultrasonic bath $(15 \mathrm{~min})$, filtered and completed to the volume with the corresponding mobile phase. Further dilution was carried out with the mobile phase to reach the specified calibration range. Triplicate $0.8 \mu \mathrm{L}$ of the prepared solutions of both drugs were injected into the chromatographic column under the previously described chromatographic conditions. The concentration of each drug was calculated using the corresponding regression equation and standard addition technique was applied.

\section{Kinetic investigation of the hydrolytic degradation products by UPLC}

One milliliter of each of DAP and FLX stock standard solution $\left(1 \mathrm{mg} \mathrm{mL} \mathrm{m}^{-1}\right)$ was separately transferred into a series of test tubes followed by the addition of $1 \mathrm{~mL}$ of $5 \mathrm{~N} \mathrm{HCl}$ solution. The test tubes were stoppered and placed in a thermostatic water bath at different temperatures $\left(60,70,80,90^{\circ} \mathrm{C}\right.$ and $\left(60,70,80^{\circ} \mathrm{C}\right)$ for DAP and FLX, respectively. Every 40 -min starting from zero time until 4 hours for DAP and every time interval of $20 \mathrm{~min}$ starting from zero time until 1.7 hour for FLX, the content of each tube was neutralized to $\mathrm{pH} 7$ by using $1 \mathrm{~mL}$ of $5 \mathrm{~N} \mathrm{NaOH}$. Each tube immediately transferred to $10 \mathrm{~mL}$ volumetric flasks, filtered and then the volume was completed with the corresponding mobile phase. The prepared solutions were chromatographed as the previously described under linearity and construction of the calibration curve. 
Citation: Soliman SM, El-Agizy HMY, El Bayoumi AEA (2017) Validated Stability -Indicating UPLC Method for Determination of Dapoxetine and Fluoxetine: Characterization of Their Hydrolytic Degradation Products, Kinetic Study and Application in Pharmaceutical Dosage Forms. Pharm Anal Acta 8: 571. doi: 10.4172/2153-2435.1000571

The concentrations of each remaining drug were calculated at each time interval and temperature. Logarithm of the percentage of the remaining drug concentration was plotted against the corresponding time interval in (h) for each temperature, and the regression equations were computed. Arrhenius plots were used to determine the activation energy (Ea), half-life $\left(t_{1 / 2}\right)$ and frequency factor $(A)$ of each drug.

\section{Results and Discussion}

\section{Optimization of chromatographic conditions}

A RP-isocratic stability-indicating UPLC method was developed as an alternative method for determination of DAP and FLX in their pharmaceutical formulations in presence of their hydrolytic degradation products(I-III). The achievement of complete separation of the target drugs from all other interferences and excipients within a short analysis time, low solvent consumption and acceptable efficiency is one of the favorable advantage of the proposed UPLC method.

Agilent Eclipse XDB C18 ( 50 x $2.1 \mathrm{~mm}$ i.d., $1.8 \mu \mathrm{m})$, zorbax SB C18 $(100 \times 2.1 \mathrm{~mm}$ i.d., $1.8 \mu \mathrm{m})$ and Agilent Eclipse XDB C18 (100 x $2.1 \mathrm{~mm}$ i.d., $1.8 \mu \mathrm{m}$ ) were tested as stationary phases. Agilent Eclipse XDB C18 ( $50 \times 2.1 \mathrm{~mm}$ i.d., $1.8 \mu \mathrm{m}$ ) column was chosen for best separation with shorter retention times.

Mobile phase systems matching trials were performed to achieve the best system that provides well resolved peaks of the drugs from their degradations. Our preliminary trials using water and acetonitrile in different ratios were tried; it was observed that retention time was found to be increase with the increase in proportion of water. This may be due to the presence of non-polar naphthalene and benzene rings in the structure of the cited drugs which increase the affinity for the non-polar stationary phase. After addition of $0.1 \%$ Phosphoric acid to acetonitrile as a mobile phase, it resulted in broad peak of DAP and FLX. As the combination of aqueous $0.03 \mathrm{M}$ ammonium acetate at $\mathrm{pH}$ 4.2 or aqueous $0.03 \mathrm{M}$ triethylamine at $\mathrm{pH} 4.3$ with acetonitrile, peak shape of the target drugs was significantly improved.

To optimize the peak separation, the flow rate was varied between at 0.1 and $0.5 \mathrm{~mL} \mathrm{~min}^{-1}$. The best resolution flow rate was at $0.2 \mathrm{~mL} \mathrm{min-}$ 1 for both drugs. The column temperatures between 25 and $45^{\circ} \mathrm{C}$ were tested. The column temperature at $25^{\circ} \mathrm{C}$ was chosen. The quantitation's of the cited drugs were performed at $210 \mathrm{~nm}$ using photodiode array detector DAD which has the advantage of selecting the best wavelength for analysis.

DAD has a major advantage for keeping both the sensitivity and stability indicating power of the proposed method by quantifying the studied drugs and detecting the degradants at their optimum wavelength. The effect of $\mathrm{pH}$ on some system suitability parameters was also studied including resolution and retention time. The retention time of the basic drugs DAP ( $\mathrm{pk}_{\mathrm{a}}$ 8.6) and FLX ( $\mathrm{pk}_{\mathrm{a}}$ 9.8) was found to be increased with the increasing of $\mathrm{pH}$ value as indicated in Table 1.

Finally, mobile phase consisting of a mixture of aqueous $0.03 \mathrm{M}$ ammonium acetate at $\mathrm{pH} 4.2$ with acetonitrile or aqueous $0.03 \mathrm{M}$ triethyl amine (TEA) at $\mathrm{pH} 4.3$ with acetonitrile in a ratio of (35: 65, $\mathrm{v} / \mathrm{v})$ or $(40: 60, \mathrm{v} / \mathrm{v})$ were used for separation of DAP, FLX, and their degradations. The two mobile phase systems were found to be optimal as to achieve minimal back ground noise and obtained well resolved peak shape.

The retention time are 1.58 and $1.85 \mathrm{~min}$ for DAP and its degradation product (Deg I) and 2.28, 2.88 and 4.32 min for FLX and its degradants (Deg I\&II), respectively (Figures 2-4).
The Linearity between the integrated peak areas and the corresponding concentrations of the drugs was studied. Linear relationship was obtained in the range of $0.05-100 \mu \mathrm{gml}^{-1}$ for DAP and 0.3-100 $\mathrm{ggml}^{-1}$ for FLX. The regression equations were:

$$
\begin{aligned}
& Y=5.447 X+1.9937(r=0.9995) \text { for DAP } \\
& Y=0.3615 X-0.3633(r=0.9997) \text { for FLX }
\end{aligned}
$$

Where $\mathrm{Y}$ is the peak area, $\mathrm{C}$ is the concentration of the compound in $\mu \mathrm{g} \mathrm{mL}{ }^{-1}$ and $\mathrm{r}$ is the correlation coefficient (Figure 5).

\section{Forced degradation study}

Forced degradation studies of the intact drug can support identification of the major degradates, establishing the degradation pathway, validate stability indicating power of the developed method and asses' stability of the studied drug.

DAP and FLX are ether containing pharmaceutical compounds, they were subjected to acid hydrolysis in aqueous solution to develop stability indicating UPLC chromatographic method.

DP was subjected to different mild and drastic degradation conditions studied according to ICH guidelines for acid stress using $0.1 \mathrm{M}, 1 \mathrm{M} \mathrm{HCl}$ for $10 \mathrm{~h}, 2 \mathrm{M}, 3 \mathrm{M} \mathrm{HCl}$ for $10 \mathrm{~h}, 4 \mathrm{M} \mathrm{HCl}$ for $20 \mathrm{~h}$ and 5 $\mathrm{M} \mathrm{HCl}$ for 20 and $30 \mathrm{~h}$. Also, stability of FLX was studied using $0.1 \mathrm{M}$, $1 \mathrm{M} \mathrm{HCl}$ for $1 \mathrm{~h}, 2 \mathrm{M} \mathrm{HC}, 3 \mathrm{M} \mathrm{HCl}$ for $1 \mathrm{~h}$ and $4 \mathrm{M}, 5 \mathrm{M} \mathrm{HCl}$ for $2 \mathrm{~h}$ as per ICH guideline [30].

Upon refluxing DAP and FLX with $5 \mathrm{M} \mathrm{HCl}$, respectively, hydrolysis of the ether group occurs, and a regular decrease in the concentration of the cited drugs with increase time intervals was observed. However, in drastic acid hydrolysis conditions, the drugs are totally degraded. The degradation product of DAP (Deg I) is (+)-N, N-dimethyl-1-phenyl-3propanolamine, where the other degradation product is Naphthalene (Deg II) which is known to be volatile (Scheme I).

The complete degradation of FLX giving two degradation products namely; N-methyl-3-hydroxy-3-phenyl propyl amine (Deg I) and $\alpha, \alpha, \alpha$-Trifluorotoluene Deg II) (Scheme II). The degradation study indicates that both the drugs undergo hydrolytic degradation at $900^{\circ} \mathrm{C}$ and FLX was found to be more susceptible to hydrolysis as compared to DAP in $5 \mathrm{M} \mathrm{HCl}$

\section{The mass spectrum}

The mass spectrum of degraded DAP showed mass ion peak at $(180.34 \mathrm{~m} / \mathrm{z})$ (Figure 6) corresponding to acid degradation product which gave the following suggestion for the molecular formula: $\mathrm{C}_{11} \mathrm{H}_{17} \mathrm{NO}(\mathrm{m} / \mathrm{z} 180.34$, Deg I). The proposal of the reaction pathway of DAP with $5 \mathrm{M} \mathrm{HCl}$ was presented in (Scheme I). The other fragment was suggested to be naphthalene which is known to be volatile.

\begin{tabular}{|c|c|c|c|}
\hline Selected drug & $\mathbf{p H}$ & Resolution & Retention time \\
\hline & 3 & 1.9 & 1.7 \\
\hline DAP & 4 & 2.2 & 1.8 \\
\hline & 4.2 & 2.68 & 1.83 \\
\hline & 4.4 & 2.55 & 2.2 \\
\hline & 5.2 & 2.5 & 2.3 \\
\hline & 3 & 1.5 & 2 \\
\hline & 4 & 2.1 & 2.15 \\
\hline & 4.3 & 2.3 & 2.28 \\
\hline & 4.5 & 2.2 & 5.2 \\
\hline & 5.3 & 2.1 & 7.1 \\
\hline
\end{tabular}

Table 1: Effect of changing $\mathrm{pH}$ on resolution and retention time of DAP and FLX using two different mobile phase systems. 
Citation: Soliman SM, El-Agizy HMY, El Bayoumi AEA (2017) Validated Stability -Indicating UPLC Method for Determination of Dapoxetine and Fluoxetine: Characterization of Their Hydrolytic Degradation Products, Kinetic Study and Application in Pharmaceutical Dosage Forms. Pharm Anal Acta 8: 571. doi: 10.4172/2153-2435.1000571
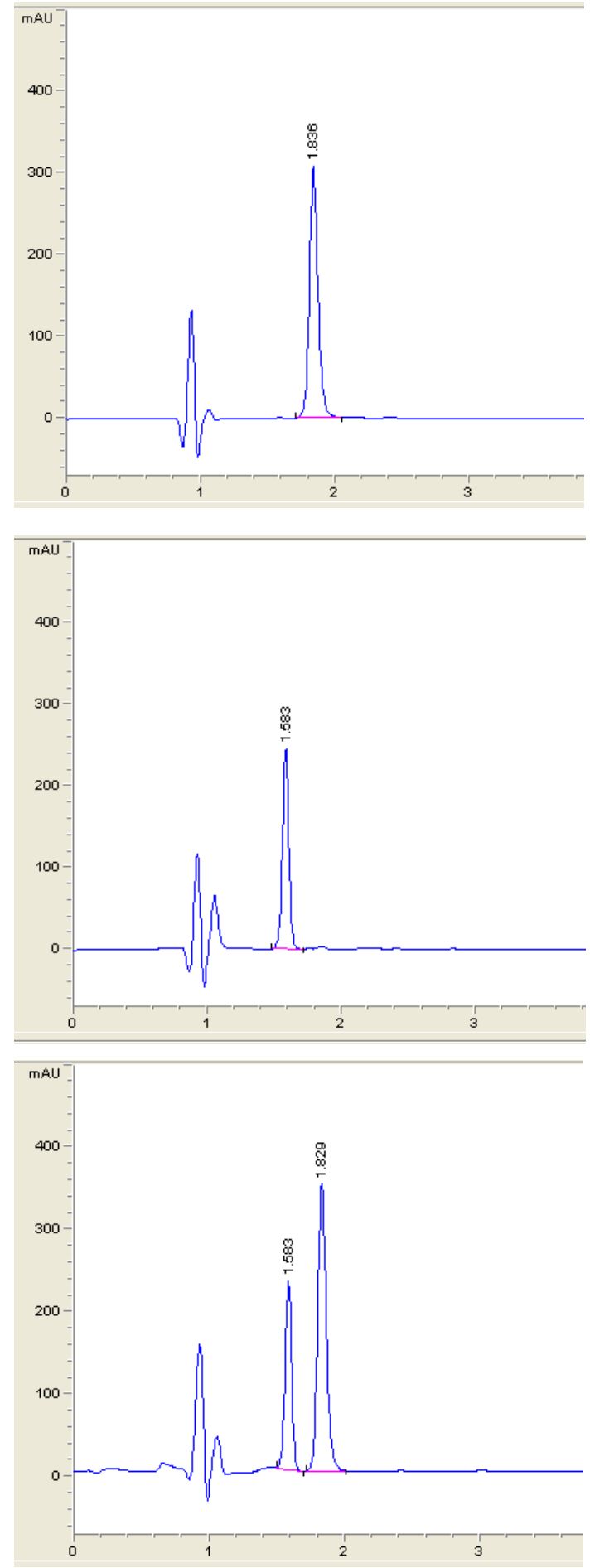

Figure 2: UPLC Chromatograms of (a) DAP, (b) degradation product of DAP, and (c) mixture of DAP and its degradation product, $(10 \mu \mathrm{g} / \mathrm{mL}$ each).

On the other hand, the mass spectra of degraded FLX showed ion peak at $(164.84 \mathrm{~m} / \mathrm{z}$ and $145.84 \mathrm{~m} / \mathrm{z}$ ) (Figure $7 \mathrm{a}$ and $7 \mathrm{~b}$ ) corresponding to hydrolitic degradation products which gave the following suggestion for the molecular formula: $\mathrm{C}_{10} \mathrm{H}_{15} \mathrm{NO}\left(\mathrm{m} / \mathrm{z} 164.84\right.$, Deg I) and $\mathrm{C}_{7} \mathrm{H}_{5} \mathrm{~F}_{3}(\mathrm{~m} / \mathrm{z}$ 145.84, Deg II). The proposal of the reaction pathway of FLX with $5 \mathrm{M}$
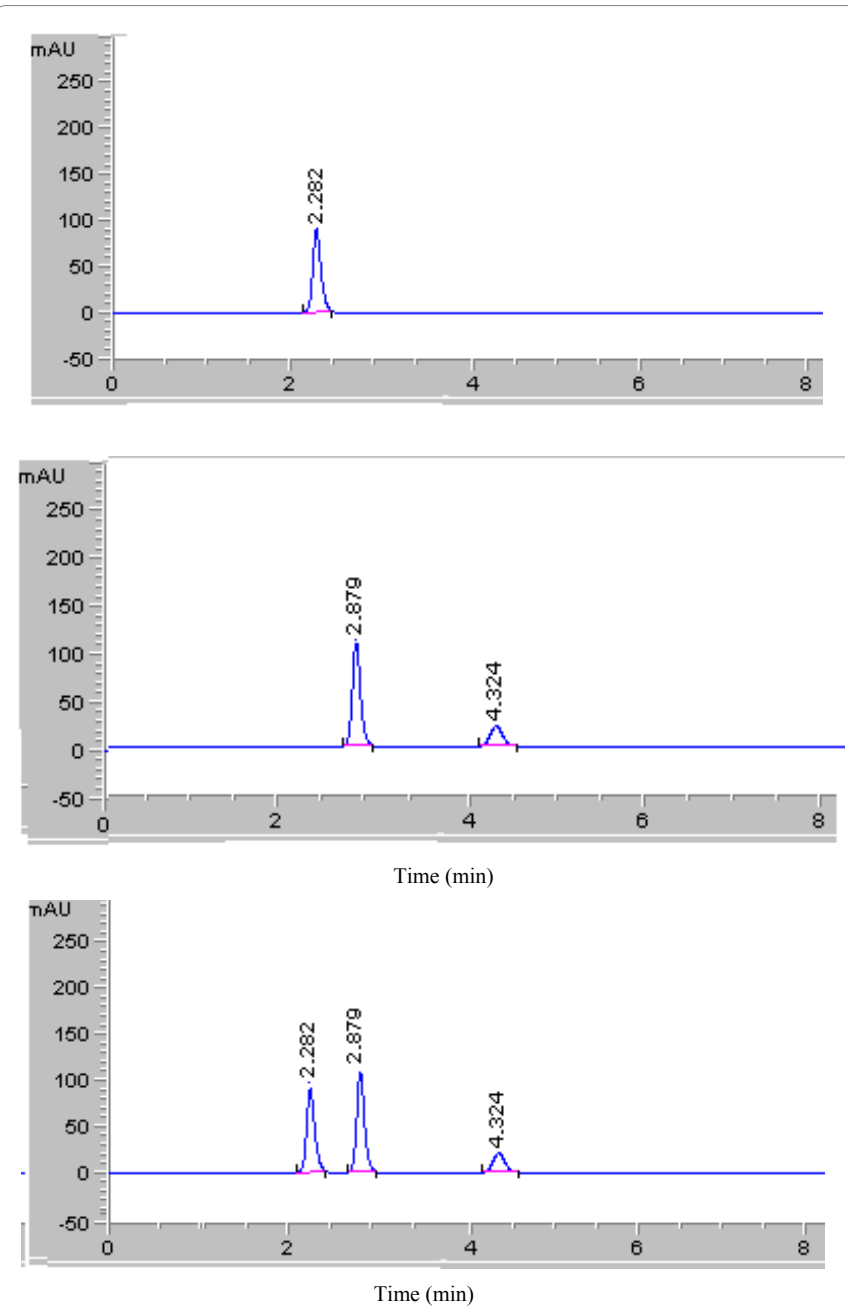

Figure 3: UPLC Chromatograms of (a) FLX, (b) degradation product of FLX (Degl and II), and (c) mixture of FLX and its degradation product, (30 $\mu \mathrm{g} / \mathrm{mL}$ each).

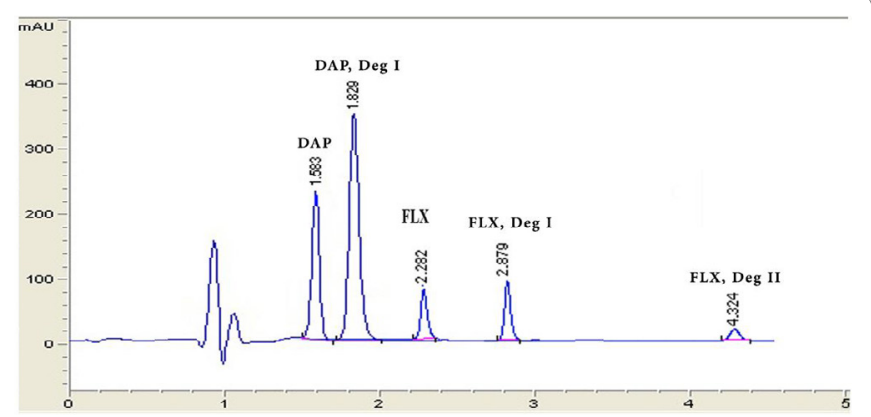

Figure 4: UPLC Chromatogram of DAP, FLX, and their degradation products using $0.03 \mathrm{M}$ ammonium acetate, $\mathrm{pH} 4.2$-acetonitrile $(35: 65, \mathrm{v} / \mathrm{v})$ or a mixture of aqueous $0.03 \mathrm{M}$ triethylamine, $\mathrm{pH} 4.3$-acetonitrile $(40: 60, \mathrm{v} / \mathrm{v})$ as two different mobile phase systems.

$\mathrm{HCl}$ was presented in (Scheme II). The Mass spectra support the suggested pathway of acid hydrolysis of DAP and FLX (Schemes I and II).

\section{Kinetic study}

In the literature, there is no kinetic study has been reported for the analysis of DAP and FLX applying UPLC technique. 
Citation: Soliman SM, El-Agizy HMY, El Bayoumi AEA (2017) Validated Stability -Indicating UPLC Method for Determination of Dapoxetine and Fluoxetine: Characterization of Their Hydrolytic Degradation Products, Kinetic Study and Application in Pharmaceutical Dosage Forms. Pharm Anal Acta 8: 571. doi: 10.4172/2153-2435.1000571
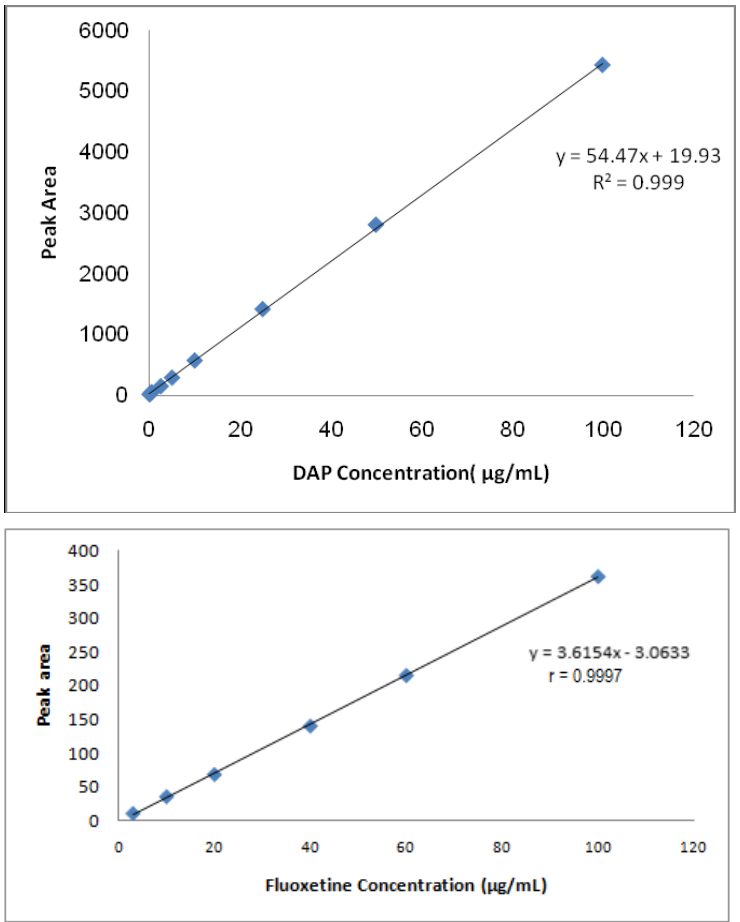

Figure 5: Calibration curves of: (a) DAP $(0.05-100 \mu \mathrm{g} / \mathrm{mL})$ and (b) FLX (3-100 $\mu \mathrm{g} / \mathrm{mL}$ by the proposed UPLC method at $210 \mathrm{~nm}$.

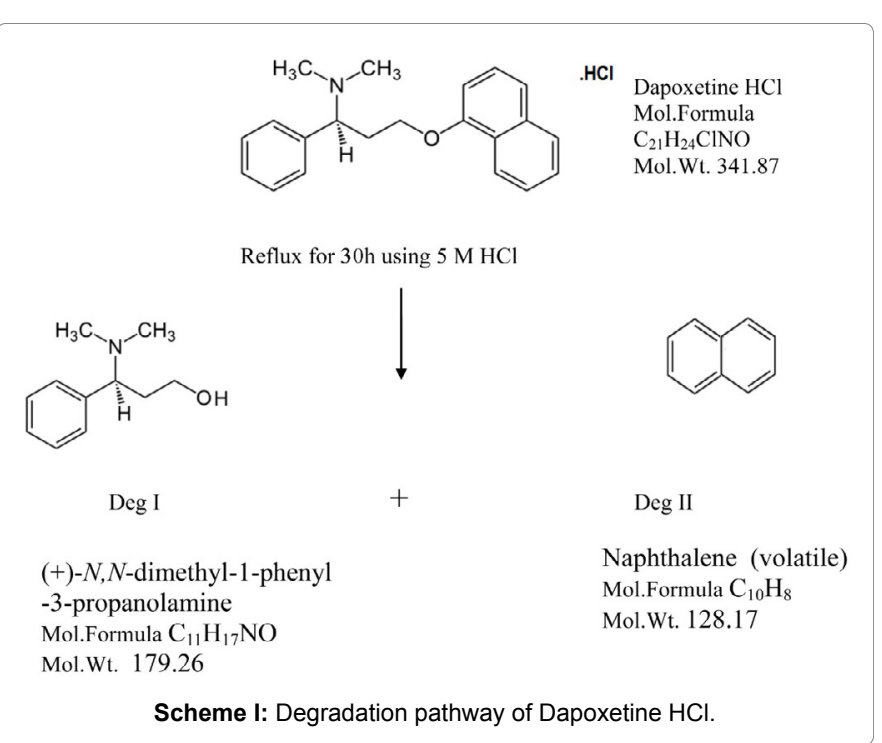

The kinetics of the acidic degradation of DAP and FLX were investigated using $5 \mathrm{~N} \mathrm{HCl}$, since the decomposition rate of DAP and FLX at lower strengths of hydrochloric acid was too slow to obtain reliable kinetic data. The proposed UPLC method was used to determine the order of the hydrolytic degradation rate of the reaction by following the regular decrease in the concentration of the intact drugs with increasing time intervals.

The influence of temperatures on the degradation processes of each drug was studied as shown in Figure $8 \mathrm{a}$ and $8 \mathrm{~b}$. Logarithm the percentages of the remaining concentration of the drugs were plotted against the corresponding time interval in hours for each temperature, and the regression equations were computed. At

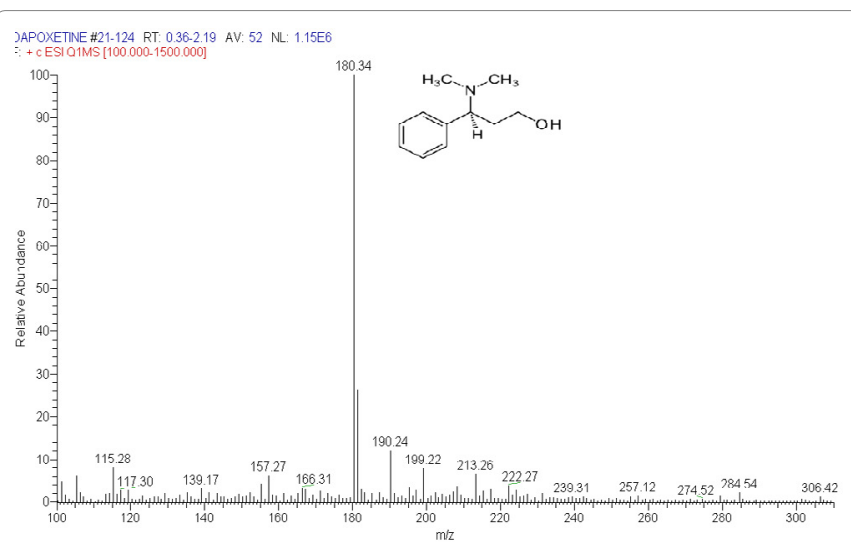

Figure 6: The mass spectrum of the acid degradation product of DAP.

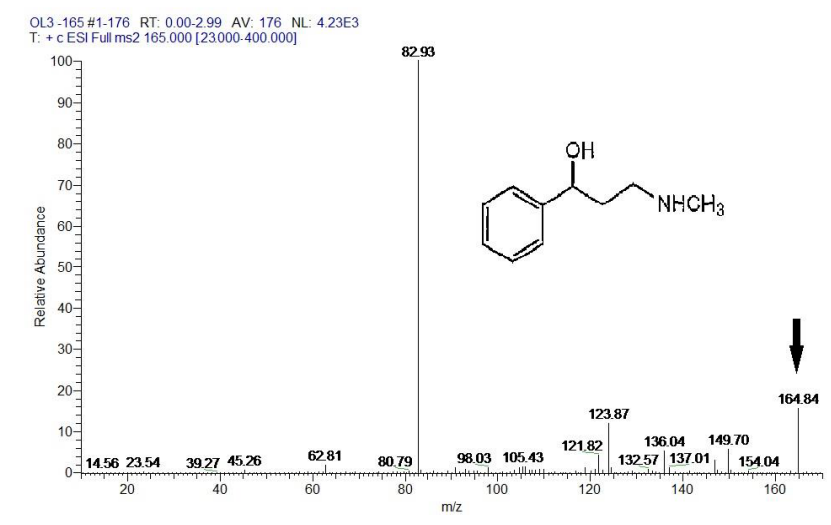

a)

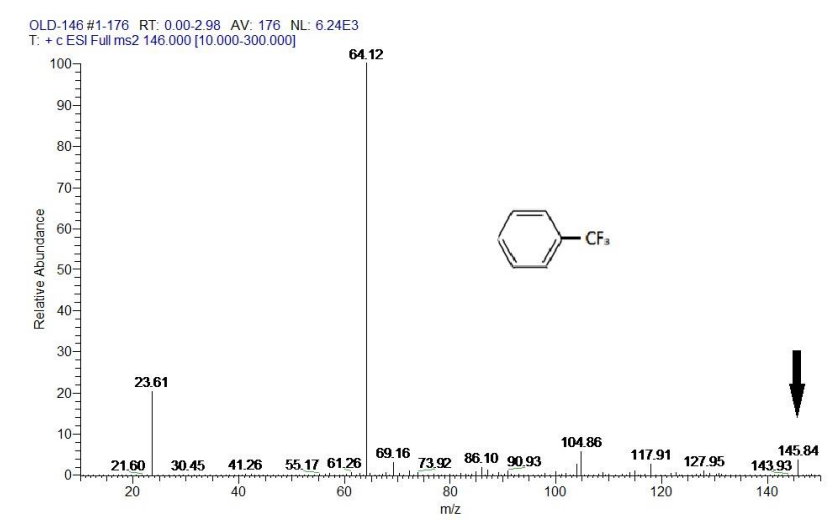

b)

Figure 7: The mass spectra of the acid degradation products of FLX (a) Deg I and (b) Deg II.

the selected temperatures $\left(90,80,70,60^{\circ} \mathrm{C}\right)$ for DAP hydrolytic degradate $\left(80,70,60^{\circ} \mathrm{C}\right)$ for FLX degradates, since $\mathrm{Na} \mathrm{OH}(5 \mathrm{M})$ was found in excess, so the previous degradation reactions of DAP and FLX followed first order kinetics where the degradation rates depended on the concentration remaining of the studied drugs and the temperature at which the degradations were conducted. Figure $8 \mathrm{a}$ and $8 \mathrm{~b}$ show that increasing the temperature leading to increasing of the reaction rate constant. 
Citation: Soliman SM, El-Agizy HMY, El Bayoumi AEA (2017) Validated Stability -Indicating UPLC Method for Determination of Dapoxetine and Fluoxetine: Characterization of Their Hydrolytic Degradation Products, Kinetic Study and Application in Pharmaceutical Dosage Forms. Pharm Anal Acta 8: 571. doi: 10.4172/2153-2435.1000571

Page 7 of 10

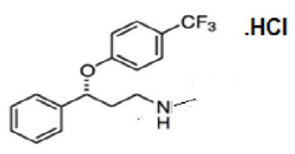

Fluoxetine $\mathrm{HCl}$ Mol. Formula $\mathrm{C}_{17} \mathrm{H}_{19} \mathrm{Cl} \mathrm{F} 3 \mathrm{NO}$ Mol.Wt. 345.79

Reflux for $2 \mathrm{~h}$ using $5 \mathrm{~N} \mathrm{HCl}$

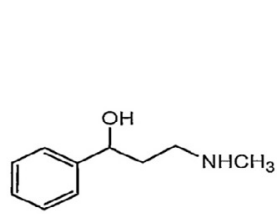

Deg I

3-hydroxy -N-methyl-3-phenyl-propylamine $\mathrm{C}_{10} \mathrm{H}_{15} \mathrm{Cl} \mathrm{F} 3 \mathrm{NO}$ $\mathrm{Mol} . \mathrm{Wt}=165.23$

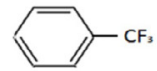

Deg II

$\alpha, \alpha, \alpha$-Trifluorotoluene Mol.Formula $\mathrm{C}_{6} \mathrm{H}_{5} \mathrm{CF}_{3}$ Mol.Wt. 146.11
Scheme II: Degradation pathway of fluoxentine HC1.

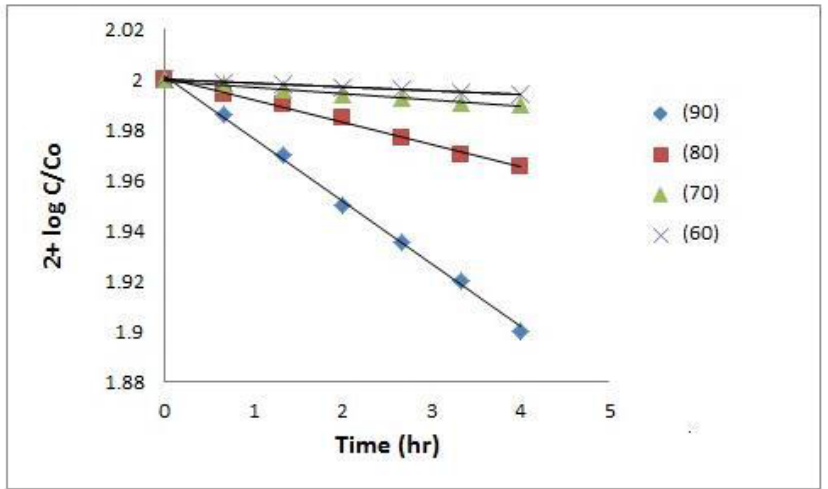

a)

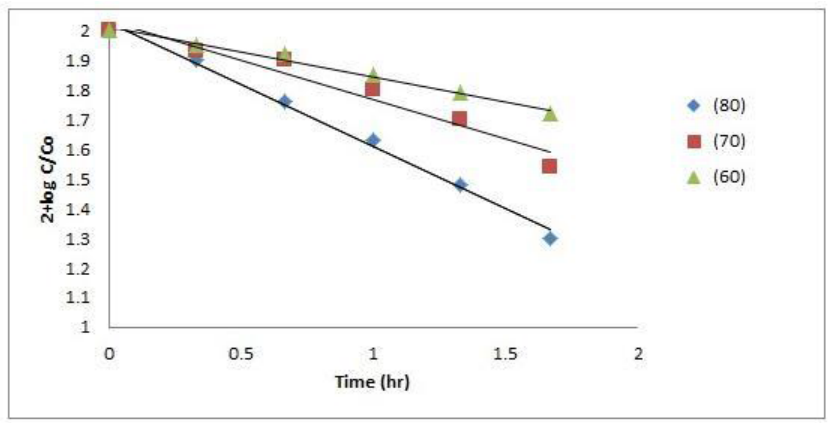

b)

Figure 8: Kinetic plot for the effect of temperature on the rate of (a) Dapoxetine $\mathrm{HCl}$ degradation reaction and (b) Fluoxetine $\mathrm{HCl}$ degradation reaction with $5 \mathrm{M}$ $\mathrm{HCl}$ using the proposed UPLC method.

From the slopes of the regression lines, it was possible to calculate the apparent first order degradation rate constants (K obs) and the halflife at each temperature was calculated in according to the following equations [31]:

$\log \left(C_{t} / C_{o}\right)+2=-K_{o b s} t, t^{1} / 2=0.693 / K_{o b s}, K_{o b s}=-2.303$ slope

Where $\mathrm{C}_{\mathrm{t}}=$ concentration remaining at time $\mathrm{t}, \mathrm{C}_{\mathrm{o}}=$ initial concentration, $\mathrm{K}_{\mathrm{obs}}=$ apparent rate constant, $\mathrm{t} 1 / 2$ is the half-life.

From the above equation, the half-lives of the drug are constant at each temperature and independent on the drug concentration.

By plotting $\log \mathrm{K}_{\mathrm{obs}}$ values versus $1 / \mathrm{T}$ (inverse absolute temperature), the Arrhenius plot was obtained and found to be linear at the selected temperature ranges (Figure $9 \mathrm{a}$ and $9 \mathrm{~b}$ ). The activation energy was calculated by applying the following equations [31]:

$\log \mathrm{K}_{\mathrm{obs}}=\log \mathrm{A}-\mathrm{Ea} 2.303 \mathrm{RT}$

Slope $=-\mathrm{Ea} / 2.303 \mathrm{R}$

Where: $\mathrm{K}$ is the reaction rate constant, $\mathrm{A}$ is the frequency factor, $\mathrm{Ea}$ is the activation energy, $\mathrm{R}$ is the universal gas constant, $\mathrm{T}$ is the absolute temperature in Kelvin.

The activation energy of DAP degradation reaction was calculated and found to be $23.3 \mathrm{Kcal} . \mathrm{mol}-1$ with frequency factor $(\mathrm{A})=7.9 \times 10^{10}$ $\mathrm{s}^{-1}$. Also, Ea of FLX degradation reaction was found to be $14.5 \mathrm{Kcal}$. mol-1 with frequency factor $(A)=9.1 \times 10^{8} \mathrm{~s}^{-1}$.

Kinetic parameters for the degradation of the cited drugs in $5 \mathrm{M}$ HCL were calculated by the proposed UPLC method and the results were represented in Table 2, which indicate instability of the studied drugs towards acidic degradation and that the activation energy of the reaction is the same at different temperature.

\section{System suitability}

System suitability parameters were calculated as per USP [32] guidelines to verify that the chromatographic system was adequate for
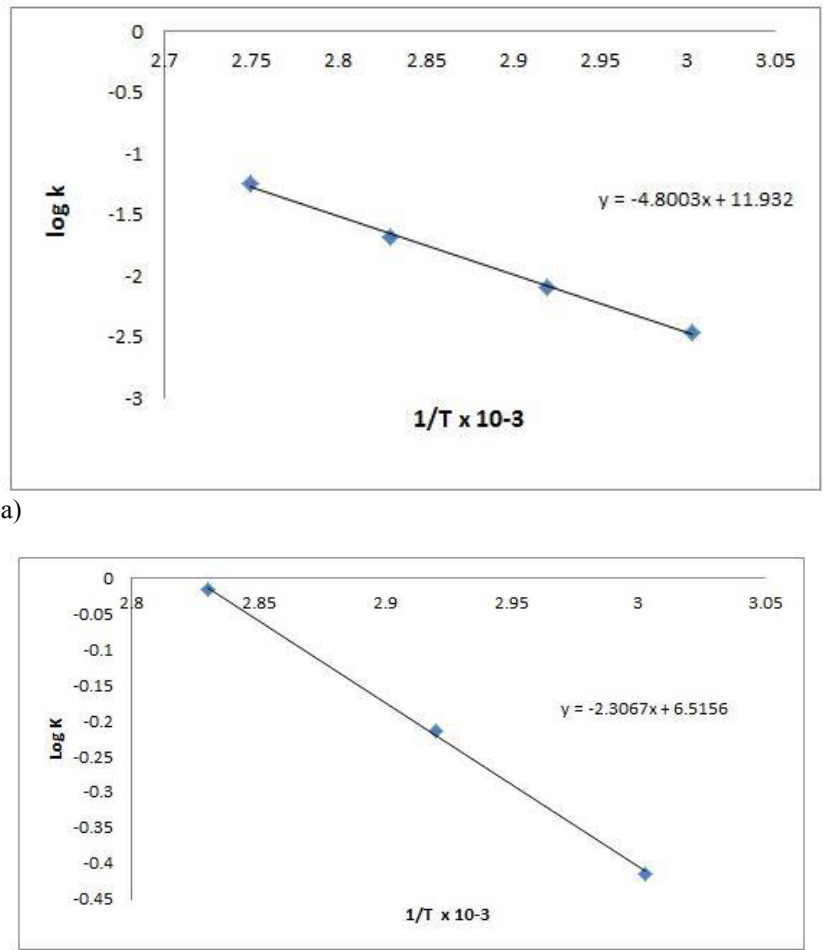

b)

Figure 9: Arrhenius plot of: (a) acidic degradation process of Dapoxetine $\mathrm{HCl}$ and (b) degradation process of Fluoxetine $\mathrm{HCl}$, in $5 \mathrm{M} \mathrm{HCl}$ using the proposed UPLC method. 
Citation: Soliman SM, El-Agizy HMY, El Bayoumi AEA (2017) Validated Stability -Indicating UPLC Method for Determination of Dapoxetine and Fluoxetine: Characterization of Their Hydrolytic Degradation Products, Kinetic Study and Application in Pharmaceutical Dosage Forms. Pharm Anal Acta 8: 571. doi: 10.4172/2153-2435.1000571

Page 8 of 10

the analysis. The parameters to be checked during the analysis were capacity factor $\left(k^{\prime}\right)$, selectivity $(\alpha)$, resolution (Rs), tailing factor $(T)$, column efficiency, HETP and RSD\% of peak areas of six replicate injections, as illustrated in Table 3.

\section{Validation of the Method}

Validation of the proposed method was performed as per ICH guidelines [33].

\section{Linearity}

Different concentrations of the standard drug solutions were injected and analyzed in triplicates under the optimized chromatographic conditions. The calibration curves were constructed between the integrated peak areas and the corresponding concentrations in the range of $0.05-100 \mu \mathrm{gml}^{-1}$ for DAP and $0.3-100$ $\mu \mathrm{gml}^{-1}$ for FLX (Figure 5). Parameters of the regression data were represented in Table 4.

\section{Accuracy Precision and accuracy}

Repeatability as intra-day precision and intermediate precision were studied using three different concentrations assayed three times repeatedly in the same lab, on the same day and in triplicate on three successive days determine variation arising from the UPLC method, which was expressed as percent relative standard deviation (\%RSD). The results of precision analysis are summarized in Table 3. Moreover, the standard addition technique was applied to evaluate the matrix effect on the recovery, the data indicate satisfactory accurate results as listed in Table 4.

The optimized methods were successfully applied for quantification of DAP and FLX in their pharmaceutical products (Joypox tablets and Prozac capsules), respectively. Accuracy and possibility of interference of excipients with the analysis of the studied drugs in their dosage forms were evaluated by recovery tests after addition of known concentrations of authentic drug to various pre-analyzed samples dosage forms.

Recovery experiments from Joypox ${ }^{\oplus}$ tablets and Prozac ${ }^{\oplus}$ capsules showed the reliability of the method. The recovery results are listed in Table 4 .

\begin{tabular}{|c|c|c|c|c|c|c|}
\hline Parameters & DAP & Deg 1 & FLX & Deg1 & Deg 2 & Recommended value* \\
\hline Retention time (min) & 1.583 & 1.829 & 2.282 & 2.879 & 4.324 & The small value indicates rapid resolution \\
\hline $\begin{array}{c}k^{\prime} \\
\text { Capacity factor }\end{array}$ & 0.96 & 1.3 & 3.5 & 4.8 & 7.6 & 1-10 acceptable \\
\hline Selectivity $(\alpha)$ & \multirow{2}{*}{\multicolumn{2}{|c|}{$\begin{array}{l}1.35 \\
2.68\end{array}$}} & \multicolumn{3}{|c|}{1.37} & $>1$ \\
\hline Resolution $\left(\mathrm{R}_{\mathrm{s}}\right)$ & & & \multicolumn{3}{|c|}{2.3} & $>2$ \\
\hline Tailing factor(T) & 1.122 & 1.003 & 1.116 & 1.166 & 1.196 & $\begin{array}{c}\leq 2 \\
\mathrm{~T}=1 \text { for a typical symmetric peak }\end{array}$ \\
\hline $\begin{array}{c}(\mathrm{N}) \\
\text { Theoretical plates }\end{array}$ & 4228 & 5056 & 11706 & 14184 & 15551 & $\begin{array}{l}\qquad>2000 \\
\text { Increases with efficiency of the separation }\end{array}$ \\
\hline HETP & $1.2 \times 10^{-3}$ & 5056 & $2.1 \times 10^{-3}$ & $1.8 \times 10^{-3}$ & $1.6 \times 10^{-3}$ & $\begin{array}{l}\text { The smaller the value, the higher the column } \\
\text { efficiency }\end{array}$ \\
\hline RSD $\%$ of peak areas & 0.23 & 0.42 & 0.41 & 0.09 & 0.11 & $R S D<1, n=6$ \\
\hline
\end{tabular}

Table 2: Kinetic parameters for the degradation of Dapoxetine and Fluxetine hydrochlorides in $5 \mathrm{M}$ HCL; Degradation rate constants, half-life, activation energy and frequency factor by the proposed UPLC method.

\begin{tabular}{|c|c|c|}
\hline Parameters & DAP & FLX \\
\hline Range $\left(\mathrm{mg} \mathrm{mL}^{-1}\right)$ & $0.05-100$ & $0.3-100$ \\
\hline \multicolumn{3}{|c|}{ Regression data } \\
\hline Slope & 5.447 & 3.6154 \\
\hline SD of slope & 0.015 & 0.043 \\
\hline Intercept & 19.937 & -3.0633 \\
\hline SD of intercept & 0.21 & 0.18 \\
\hline Correlation coefficient (r) & 0.9995 & 0.9997 \\
\hline$S D$ of $(r)$ & 0.017 & 0.05 \\
\hline LOD/LOQ $\left(\mathrm{mg} \mathrm{mL}^{-1}\right) \mathrm{a}$ & $0.013 / 0.040$ & $0.089 / 0.27$ \\
\hline \multicolumn{3}{|c|}{ Accuracy b } \\
\hline Drug substance & $99.41 \pm 1.02$ & $100.05 \pm 0.89$ \\
\hline Drug product & $99.57 \pm 0.91$ & $100.10 \pm 0.71$ \\
\hline Added standard & $99.98 \pm 0.26$ & $100.24 \pm 0.80$ \\
\hline Specificityc ( \pm RSD \%) & $100.26 \pm 0.70$ & $99.68 \pm 1.14$ \\
\hline \multicolumn{2}{|c|}{ Precision ( \pm RSD \%) } & \\
\hline Intra-day d & \pm 0.55 & \pm 0.71 \\
\hline Inter-daye & \pm 0.59 & \pm 0.92 \\
\hline
\end{tabular}

a Mean of nine determinations. ${ }^{\mathrm{b}}$ Mean of six determinations $\pm \mathrm{SD}$

c Specificity (mean \pm SD) for the laboratory prepared mixtures.

${ }^{d}$ The intra-day $(n=9)$, RSD of three concentrations $\left(5,10,25 \mu \mathrm{gL}^{-1}\right)$ of DAP and $\left(10,20,40 \mu \mathrm{g} \mathrm{mL}^{-1}\right)$ of FLX repeated three times within the day.

e The inter-day $(n=9)$, RSD of three concentrations $\left(5,10,25 \mu \mathrm{gLL}^{-1}\right)$ of DAP/(10,20, $\left.40 \mu \mathrm{g} \mathrm{mL}^{-1}\right)$ of FLX repeated three times in three successive days.

Table 3: Parameters of assay validation results of the UPLC methods for the determination of DAP and FLX in their drug substances 
Citation: Soliman SM, El-Agizy HMY, El Bayoumi AEA (2017) Validated Stability -Indicating UPLC Method for Determination of Dapoxetine and Fluoxetine: Characterization of Their Hydrolytic Degradation Products, Kinetic Study and Application in Pharmaceutical Dosage Forms. Pharm Anal Acta 8: 571. doi: 10.4172/2153-2435.1000571

Page 9 of 10

\section{Selectivity}

The Selectivity of UPLC method was proved by analysis of Laboratory-prepared mixtures containing different percentages of the cited drugs and their degradation products. The proposed method was specific for the determination of DAP and FLX in presence of up to $90 \%$ in presence of their degradation products without interference as shown in Table 5 .

Statistical omparisons were performed on the results of both drugs assay. Students $\mathrm{t}$ - and F- values revealed no significant difference between the proposed and the reported methods with respect to accuracy and precision (Table 6).

\section{Robustness of the proposed method}

The effect of a small change in the mobile phase composition and variation in $\mathrm{pH}$ value $( \pm 0.2)$ was studied on the peak area. The RSD $\%$ of peak areas was calculated for each parameter and was found to be less than $2 \%$. The low values of RSD \% indicated that the method is robust.

\begin{tabular}{|c|c|c|}
\hline \multirow{2}{*}{$\begin{array}{c}\text { Degradation } \% \\
(\mathbf{w} / \mathbf{w})\end{array}$} & \multicolumn{2}{|c|}{ Recovery ${ }^{\text {a }}$ of intact drug $\%$} \\
\hline 5 & DAP & FLX \\
\hline 10 & 99.89 & 99.68 \\
\hline 30 & 100.30 & 101.10 \\
\hline 50 & 99.30 & 100.40 \\
\hline 80 & 101.10 & 98.20 \\
\hline 90 & 100.70 & 99.00 \\
\hline Mean \pm RSD & 99.90 & 100.05 \\
\hline
\end{tabular}

a Average of three determinations.

Table 4: Selectivity of the proposed UPLC methods for the determination of Dapoxetine and Fluxetine hydrochlorides with their degradation products in laboratory prepared mixtures.

\begin{tabular}{|c|c|c|c|c|c|c|c|c|}
\hline \multirow[t]{2}{*}{ Parameter } & \multicolumn{2}{|c|}{ pure forms } & \multicolumn{2}{|c|}{$\begin{array}{c}\text { Reported } \\
\text { methods } \\
{[12,21]}\end{array}$} & \multicolumn{2}{|c|}{$\begin{array}{c}\text { pharmaceutical } \\
\text { preparation }\end{array}$} & \multicolumn{2}{|c|}{$\begin{array}{c}\text { Reported } \\
\text { methods } \\
{[12,21]}\end{array}$} \\
\hline & DAP & FLX & DAP & FLX & $\begin{array}{c}\text { Joypox } \\
\circledR \text { tablets }\end{array}$ & $\begin{array}{l}\text { Prozac } \AA \\
\text { capsules }\end{array}$ & DAP & FLX \\
\hline Mean & 99.28 & 100.33 & 99.22 & 99.45 & 99.57 & 100.10 & 99.51 & 99.39 \\
\hline SD & 0.77 & 0.63 & 1.35 & 1.01 & 0.91 & 0.71 & 0.43 & 0.65 \\
\hline Variance & 0.5929 & 0.3969 & 1.8225 & 1.0201 & 0.8215 & 0.4985 & 0.1832 & 0.6532 \\
\hline $\mathrm{n}$ & 5 & 5 & 5 & 5 & 5 & 5 & 5 & 5 \\
\hline $\begin{array}{l}\text { t-value } \\
(2.306)^{*}\end{array}$ & 0.09 & 1.65 & & & 0.13 & 1.65 & & \\
\hline $\begin{array}{l}\text { F -value } \\
(6.400)^{*}\end{array}$ & 3.07 & 2.57 & & & 4.48 & 1.55 & & \\
\hline
\end{tabular}

*The values between parentheses are the theoretical values of $t$ and $F$ at $(P=0.05)$

Table 5: Statistical comparison between the proposed UPLC method and the reported methods for the determination of DAP and $F$ LX in pure forms and pharmaceutical preparations.

\begin{tabular}{|c|c|c|c|c|c|c|c|c|}
\hline \multicolumn{4}{|c|}{ Dapoxetine hydrochloride } & \multicolumn{3}{c|}{ Fluoxetine hydrochloride } \\
\hline $\begin{array}{c}\text { Temp } \\
{ }^{\circ} \mathrm{C}\end{array}$ & $\mathrm{K}\left(\mathrm{h}^{-1}\right)$ & $\mathrm{t}_{1 / 2}(\mathrm{~h})$ & $\begin{array}{c}\mathrm{Ea} \\
\mathrm{Kcal}^{\prime} \mathrm{mol}^{-1}\end{array}$ & $\mathrm{~A}\left(\mathrm{~s}^{-1}\right)$ & $\mathrm{K}\left(\mathrm{h}^{-1}\right)$ & $\mathrm{t}_{1 / 2}(\mathrm{~h})$ & $\begin{array}{c}\mathrm{Ea} \\
\mathrm{Kcal} . \\
\mathrm{mol}^{-1}\end{array}$ & $\mathrm{~A}\left(\mathrm{~s}^{-1}\right)$ \\
\hline 60 & 0.00345 & 200.8 & 23.3 & $7.9 \times 10^{10}$ & 0.385 & 1.8 & 14.5 & $9.1 \times 10^{8}$ \\
\hline 70 & 0.00576 & 120.3 & 23.3 & $7.9 \times 10^{10}$ & 0.61 & 1.13 & 14.5 & $9.1 \times 10^{8}$ \\
\hline 80 & 0.02049 & 33.5 & 23.3 & $7.9 \times 10^{10}$ & 0.965 & 0.75 & 14.5 & $9.1 \times 10^{8}$ \\
\hline 90 & 0.05757 & 12.04 & 23.3 & $7.9 \times 10^{10}$ & & & & \\
\hline
\end{tabular}

Table 6: Kinetic parameters for the degradation of Dapoxetine and Fluxetine hydrochlorides in $5 \mathrm{M} \mathrm{HCL}$; Degradation rate constants, half-life, activation energy and frequency factor by the proposed UPLC method.

\section{Conclusion}

New isocratic UPLC method was developed for separation of DAP and FLX in presence of their major degradation products confirmed as (+)-N, N-dimethyl-1-phenyl-3-propanolamine, N-methyl-3-hydroxy3-phenyl propyl amine and, $\alpha$, $\alpha$, $\alpha$-Trifluorotoluene. Significant advantages over other methods proposed in literature were found in decrease time of analysis, minimize solvent consumption and significant reduction in run time when compared with other reported methods.

Another advantage of the method over the already reported ones $[13,15,16,25,26]$ was that, the suffered organic solvent for each analysis was $0.4 \mathrm{~mL} 2 \mathrm{~min}^{-1}$ and $0.5 \mathrm{~mL} 5 \mathrm{~min}^{-1}$ for DAP and FLX. Total solvent consumption using the proposed UPLC was significantly reduced over the already published method [16] which used $0.5 \mathrm{~mL}$ $\mathrm{min}^{-1}$ flow rate with the gradient program and consumed nearly 20 $\mathrm{mL}$ acetonitrile and about $80 \mathrm{ml}$ buffer for each assay. The proposed method is rapid and consumed less solvent than the published one $[16,25,26]$. Solvent consumption, analysis time and cost of analysis are important in quality control laboratories. The proposed UPLC method could be used for analysis of the two SSRI drugs in presence of three known hydrolytic degradation products, irrespective to the diversity in their chemical structures. The UPLC systems are superior in analysis time and solvent consumption. These advantages give the method great value as alternative in routine analysis of the SSRI drugs in their pharmaceutical formulations.

\section{Conflicts of Interest}

The authors stated that "There are no conflicts of interest to declare".

\section{References}

1. Potter WZ, Hollister LE (2007) Antidepressant Agents, in Lange: Basic and Clinical Pharmacology-Antidepressant Agent, Katzung B G, McGraw-Hill, New York, NY, USA: 475-480.

2. Royal Pharmaceutical Society of Great Britain (2008): 204-208.

3. Aggarwal A, Jethani SL, Rohatgi RK, Kalra J (2017) The role of selective serotonin reuptake inhibitors in premature ejaculation. EMJ 3: 78-81.

4. Hatzimouratidis K (2012) European Association of Urology. Guidelines on male sexual dysfunction: Erectile dysfunction and premature ejaculation.

5. Sweetman SC (2014) The complete Drug Reference, The Pharmaceutical Press, London, UK 38: 2354-2372.

6. Soliman SM, El-Agizy HMY, El Bayoumi AE (2014) Derivative synchronous fluorescence spectroscopy for the simultaneous determination of dapoxetine hydrochloride and vardenafil in binary mixtures. J Appl Spectrosc 81: 509-518.

7. Chapla B, Amin G, Pandya A, Kakadiya J, Shah N (2012) Simultaneous estimation and validation of vardenafil and dapoxetine hydrochloride in pharmaceutical formulation by thin layer chromatographic densitometric method. Int Res J Pharm (IRJP) 3: 480-483.

8. Neumajer G, Sohajda T, Darcsi A, Tóth G, Szente L, et al. (2012) Chira recognition of dapoxetine enantiomers with methylated-gamma-cyclodextrin A validated capillary electrophoresis method. Pharm Biomed Anal 62: 42-47.

9. Giri AD, Bhusari VK, Dhaneshwar SR (2012) Validated HPLC method for simultaneous quantitation of tadalafil and dapoxetine hydrochloride in bulk drug and formulation. Int J Pharm Pharm Sci 4: 654-658.

10. Sandhya Madhuri M, Sathyaraj A, Lanka S (2013) Development and validation of RP-HPLC method for the estimation of dapoxetine hydrochloride in tablet forms. Int J Pharm Sci Rev Res 14: 31-37.

11. Kapavarapu S, Chintala R (2016) Validated stability indicating rp-hplc method for the determination of dapoxetine hydrochloride in bulk and pharmaceutical formulations. Anal Chem Indian J 16: 363-373. 
Citation: Soliman SM, El-Agizy HMY, El Bayoumi AEA (2017) Validated Stability -Indicating UPLC Method for Determination of Dapoxetine and Fluoxetine: Characterization of Their Hydrolytic Degradation Products, Kinetic Study and Application in Pharmaceutical Dosage Forms. Pharm Anal Acta 8: 571. doi: 10.4172/2153-2435.1000571

12. Patil RB, Deshmukh TA, Patil VP (2014) Stability-indicating HPLC methods for determination of dapoxetine $\mathrm{HCL}$ in bulk drug and formulation. Int J Pharm Pharm Sci 6: 687-690.

13. Liew KB, Peh KK (2014) Stability indicating HPLC-UV method for determination of dapoxetine $\mathrm{HCl}$ in pharmaceutical product. Acta Pol Pharm 71: 393-400.

14. Kalyani K, Anuradha V (2015) Der Pharmacia Lettre 7: 98-106.

15. Rohith T, Ananda S (2013) Development and validation of high performance liquid chromatography method for the determination of process related impurities in dapoxetine hydrochloride. IJRPC 3: 74-82.

16. Tambe VS, Deodhar MN, Prakya V (2016) Stability-indicating UPLC-MS/UV Method for Simultaneous Determination of Sildenafil Citrate and Dapoxetine Hydrochloride from Bulk and Formulation. Indian J Pharm Sci 78: 663-672.

17. Darwish IA, Amer SM, Abdine HH, Al-Rayes LI (2009) New spectrophotometric and fluorimetric methods for determination of fluoxetine in pharmaceutical formulations. Int J Anal Chem 1-9.

18. Berzas Nevado JJ, Villaseñor Lleren MJ, Contento Salcedo AM, Aguas Nuevo E (2000) Determination of Fluoxetine, Fluvoxamine, and Clomipramine in Pharmaceutical Formulations by Capillary Gas Chromatography. J Chromatogra Sci 38: 200-206.

19. Cherkaoui S, Veuthey JL (2002) Nonaqueous capillary electrophoresiselectrospray- mass spectrometry for the analysis of fluoxetine and its related compounds. Electrophoresis 23: 442-448.

20. Patel S, Patel NJ (2009) Simultaneous RP-HPLC and HPTLC estimation of fluoxetine hydrochloride and olanzapine in tablet dosage forms. Indian J Pharm Sci 71: $477-480$

21. Shah CR, Shah NJ, Suhagia BN, Patel NM (2007) Simultaneous Assay of Olanzapine and Fluoxetine in tablets by Column High-Performance Liquid Chromatography and High-Performance Thin-Layer Chromatography. J AOAC Int 90: 1573-1578.

22. Raggi MA, Casamenti, G, Mandrioli R, Sabbioni C, Volterra V (1998) Determination of fluoxetine and norfluoxetine in human plasma by highpressure liquid chromatography with fluorescence detection. J Pharm Biomed Anal 18: 193-199.

23. Yilmaz N, Ozkan Y, Ozan SA, Biryol I, Aboul-Enein HY (2000) High performance liquid chromatographic assay and drug dissolution studies of fluoxetine hydrochloride in capsule formulations. J Liq Chromatogr Relat Technol 23 1699-1710.

24. Shah CR, Suhagia BN, Shah NJ, Patel DR, Patel NM (2008) Stability-indicating simultaneous HPTLC method for olanzapine and fluoxetine in combined tablet dosage form. Indian J Pharm Sci 70: 251-255

25. Dudhrejiya A, Gandhi K, Maru M, Sheth N (2014) Development and validation of stability-indicating RP- HPLC method for simultaneous estimation of sildenafil citrate and fluoxetine in bulk and tablet dosage form. Int Bull Drug Res 4: 92-105.

26. Pathak A, Rajput SJ (2009) Development of a stability-indicating HPLC method for simultaneous determination of olanzapine and fluoxetine in combined dosage forms. J Chromatogr Sci 47: 605-611.

27. Ezzeldin E, Abo-Talib NF, Tammam MH (2017) UPLC Tandem mass spectrometry for the simultaneous determination of fluoxetine, risperidone and its active metabolite 9-hydroxy risperidone in plasma: Application to pharmacokinetics study in rats. J Anal Methods Chem 2017: 1-10.

28. Alves V, Goncalves J, Conceicão C, Teixeira HM, Câmara JS (2015) An improved analytical strategy combining microextraction by packed sorbent combined with ultra-high-pressure liquid chromatography for the determination of fluoxetine, clomipramine and their active metabolites in human urine. $J$ Chromatog A 1408: 30-40.

29. Nováková L, Matysová L, Solich P (2006) Advantages of application of UPLC in pharmaceutical analysis. Talanta 68: 908-918

30. ICH guideline Q1A (R2) (2000) Stability testing of new drug substances and products.

31. El-Kosasy AM, Hussein LA, Salama NN, Sedki NG (2015) Kinetic study and peak purity determination of bupropion hydrochloride using RRLC/DAD and HPLC/MWD methods: stability study and application in pharmaceutical preparation and in synthetic mixtures with nicotine. RSC Adv 5: 64274-64285.

32. The United States Pharmacopoeia (2014) $37^{\text {th }}$ edn, the National Formulary NF 32, USA, U.S. Pharmacopoeial Convention, Rockville, MD

33. ICH guideline Q2 (R1), Validation of Analytical Procedures: Text and Methodology, London, UK, 2005. 